Katarzyna Seroka

Warszawa

\title{
Z testamentu Juliana Ursyna Niemcewicza. Dary książkowe dla Biblioteki Polskiej w Paryżu
}

Julian Ursyn Niemcewicz, jeden z najwybitniejszych przedstawicieli Wielkiej Emigracji, przebywał we Francji od końca 1833 r. aż do swojej śmierci w maju 1841 r. Okres ten spędził niezwykle aktywnie. Pozostawał w stałym kontakcie z polskimi emigrantami, ale także z Francuzami, przypominał o sprawie narodowej, o represjach, więzieniu Polaków oraz o zagrabianiu dóbr kultury. Był też pomysłodawcą wielu działań na rzecz polskiej diaspory - to m.in. $\mathrm{z}$ jego inicjatywy powstały liczne emigracyjne stowarzyszenia oraz towarzystwa naukowe i kulturalne.

J.U. Niemcewicz był zaangażowany w działalność Towarzystwa Naukowej Pomocy (TNP), które działało na rzecz rozwoju nauki, oświaty i kultury wśród polskiej emigracji. Szczególny nacisk kładziono w nim na edukację młodzieży, który to proces starano się wesprzeć poprzez wykładanie pieniędzy na szkoły, stypendia oraz zasiłki. W łonie Towarzystwa od początku zwracano uwagę na konieczność zorganizowania polskiej drukarni oraz biblioteki - upatrywano w tym nadzieję na podtrzymanie za pomocą języka i słowa pisanego polskiej tożsamości'. W 1833 r. udało się Bibliotekę powołać ${ }^{2}$ Gromadzony księgozbiór opierał się na zakupach i przekazywanych darach, a wśród darczyńców nie zabrakło J.U. Niemcewicza, który 18 listopada 1836 r. na posiedzeniu Rady TNP zadeklarował, iż swój prywatny księgozbiór zapisuje testamentem na rzecz tejże Biblioteki ${ }^{3}$. Ostatecznie, o czym dalej, testament swój zmodyfikował i przekazał woluminy innej książnicy, jednak już wtedy dał świadectwo, jak ważne było dla niego, aby swoimi lekturami wspierać emigracyjne biblioteki.

1 Biblioteka Polska w Paryżu (dalej BPP), rps sygn. 612/II, Protokoły posiedzeń Towarzystwa Naukowej Pomocy, „Myśli ogólne o zawiązaniu Towarzystwa w zamiarach utrzymania na przyszłość Języka i Narodowości Polskiej teraz na zupełny upadek wystawionych”, s. 41-52.

2 Zob. J. Pezda, Historia Biblioteki Polskiej w Paryżu w latach 1838-1893, Kraków 2013, s. $26-28$.

3 Zob. tamże, s. 29-30. 
Ponadto J.U. Niemcewicz od początku współpracował z - założonym również w 1832 r. - Towarzystwem Literackim Polskim, a także pełnił funkcję prezesa powstałego w jego strukturze cztery lata później Wydziału Historycznego. Sekcja ta miała za zadanie gromadzić wszelkie materiały historyczne o Polsce ze źródeł zagranicznych. Mimo sędziwych lat J.U. Niemcewicz należał do osób najczęściej i najregularniej uczęszczających na posiedzenia Towarzystwa. W relacji Lubomira Gadona można przeczytać:

Mijały miesiące, w których on ani jednej sesji nie opuścił. A nie tylko samą obecnością, swą łagodną, dobroduszną twarzą, owianą długimi kosmykami białych włosów, i dobrym humorem ożywiał je, ale i przemowami, odczytywaniem swych prac wierszem lub prozą i rozlicznymi wiadomościami, czerpanymi z długoletniego doświadczenia i wspomnieńn .

Ponadto wspierał finansowo organizację tychże posiedzeń oraz aktywnie przygotowywał wypisy 5 .

Jako prezes Wydziału Historycznego zaproponował w lipcu 1838 r. połączenie księgozbiorów bibliotek już funkcjonujących w licznych towarzystwach działających pod patronatem obozu Adama Jerzego Czartoryskiego i scalenia tych zbiorów w jedną narodową książnicę . Pomysł ten udało się zrealizować i pod koniec tegoż roku powstała Biblioteka Polska w Paryżu (BPP), której jednym z najważniejszych darczyńców był sam J.U. Niemcewicz. Jego organizacyjny, materialny i intelektualny wkład w powołanie do życia tej jakże ważnej dla rodaków instytucji należy uznać za nieoceniony.

J.U. Niemcewicz uchodził za dobrego ducha Biblioteki Polskiej. Helena Salska pisze o nim:

jowialny i poczciwy staruszek, $w$ granatowym surducie i aksamitnej czapeczce na głowie, krzątał się mile po Bibliotece, ożywiając swoim ostrym dowcipem i stałym niefrasobliwym humorem zebrania Wydziału. Przekomarzał się nieraz z Karolem Sienkiewiczem?

4 L. Gadon, Z życia Polaków we Francji. Rzut oka na 50-letnie koleje Towarzystwa Historyczno-Literackiego w Paryżu (1832-1882), Paryż 1883, s. 35.

5 „Wczoraj zebrali się do mnie, wyznaczeni przez Towarzystwo Literackie do szukania pamiętników do historii naszej, koledzy: Sienkiewicz, Załuski, Kożuchowski, Oleszczyński. [...] Oddałem Panu Sienkiewiczowi już zebrane przeze mnie podobne materiały w Muzeum brytanicznym, wypisy w 13 i 15 wieku podróżujących przez Polskę, życie Jana Łaskiego, przyjaciela Erazma z Rotterdamu itd. Ustanowiono co środa zbierać się u mnie, co środa wieczór, o godz. 7. Opał, światło, herbatę trzeba będzie szafować, nie żal na cel tak zbawienny" - J.U. Niemcewicz, Dzienniki 1835-1836, Warszawa 2005, s. 376.

6 BPP, rps sygn. 1536, List J.U. Niemcewicza do A.J. Czartoryskiego z dnia 3 lipca 1838, s. 223-224.

7 Archiwum Polskiej Akademii Nauk w Warszawie (dalej Arch. PAN w Warszawie), sygn. III-5, H. Salska, Towarzystwo Historyczno-Literackie z czasów Wielkiej Emigracji 1832-1892 [maszynopis niepublikowany], s. 109. 
Jako ogromny zwolennik funkcjonowania książnicy i jej stały bywalec, wpierał ją wielokrotnie licznymi darami, nie tylko książkowymi. Niedługo po powołaniu Biblioteki, w kwietniu 1839 r., ofiarował na jej rzecz 59 woluminów książek ${ }^{8}$ oraz węgiel ziemny amerykański, posiadane medale, a także zegar stojący9.

Ofiarowane pozycje wydawnicze cechowała różnorodna tematyka. Najstarsza publikacja to dzienniki z podróży brytyjskiego historyka Williama Coxe'a Voyage en Pologne, Russie, Suède, Dannemarc etc., wydane w Genewie w 1786 r. ${ }^{10}$ Pozostałe książki pochodziły z lat 1823-1839. Wśród nich przeważały polskie publikacje, tłumaczenia autorów polskich i polskiego pochodzenia, jak np. Bataille de Kircholm, ou l'amour d'une Anglaise... (Paris 1836) autorstwa kapitana Henryka Krasińskiego, Un mot sur la question d'Afrique (Paris 1837) napisane przez syna Napoleona i Marii Walewskiej, Aleksandra Colonny-Walewskiego (warszawskie wydanie z 1831 r.), Kroniki wieku XII, czyli dziejów Władystawa I, Bolesława III, Władysława II i Bolesława IV, monarchów polskich, z księgi IV i V kompilacji Dtugosza wyttumaczone Przybysława Dyamentowskiego.

Wśród darowanych woluminów znajdowały się również druki ulotne i czasopisma: Kalendarz na rok 1838, Zdanie sprawy z czynności Komitetu Litewskiego (Paryż 1837), „Kraj i Emigracja” - zeszyty 1 i 2 (Paryż 1835) czy „Rocznik Emigracji Polskiej” - nr 28 (Paryż 1836). J.U. Niemcewicz przekazał ponadto kilka własnych dzieł, m.in. biografię księcia A.J. Czartoryskiego $^{11}$, listy do Karola Kniaziewicza ${ }^{12}$ oraz Śpiewy historyczne ${ }^{13}$.

W przekazanych darach znalazło się kilka publikacji zagranicznych, w tym Discours prononcé sur la tombe de Gros... Jeana-Baptiste'a Delestre'a (Paris 1835) czy wydana w Londynie w 1835 r. Frithiof's Saga szwedzkiego pisarza Esaiasa Tegnéra. Do Biblioteki Polskiej trafiły też broszury, jak np. wydane w Nowym Jorku sprawozdanie First report of the West-Chester County Temperance Society: presented at the annual meeting,

\footnotetext{
8 BPP, rps sygn. 1656, Spis Xiążek ofiarowanych do Biblioteki Polskiej przez JW. Kasztelana Niemcewicza, s. 53-54.

9 Zob. I. Rusinowa, Wstęp, [w:] J.U. Niemcewicz, Dziennik 1839-1841, Pułtusk 2008, s. 8.

10 Książka Coxe'a opowiada o najnowszej historii krajów, które autor odwiedził w trakcie podróży. W części o Rzeczypospolitej wspomina o historii i rewolucjach, m.in. elekcji Stanisława Augusta, I rozbiorze, sejmie konfederacyjnym z 1776 r. i jego konsekwencjach, a także o sytuacji współczesnej. Publikacja jest bogato ilustrowana, zawiera m.in. mapę Polski wykonaną przez angielskiego kartografa Thomasa Kitchina oraz portret Stanisława Augusta.

11 Zob. Biographie du prince Adam Georges Czartoryski, exprésident du gouvernement national de Pologne, Paris 1835.

12 Zob. Niemcewicz au général Kniaziewicz, épître traduite du polonais par J.-C. Ostrowski, Paris 1836.

13 Zob. J.U. Niemcewicz, Śpiewy historyczne..., pod względem historyi uważane przez Joachima Lelewela, Kraków 1835.
} 
at White-Plains, August 12, 1830, together with the address of the president czy Commercial Relations between England and Ireland (London 1838). Te skromne dary dały początek wspaniałej emigracyjnej tradycji, kontynuowanej nie tylko przez J.U. Niemcewicza - ofiarowywania książek na cele narodowe, naukowe i kulturalne.

Gdy J.U. Niemcewicz zaczął zdawać sobie sprawę z nadchodzącego kresu swojego życia ${ }^{14}$, sporządził testament (12 grudnia 1838 r.). Dokonał tego w obecności dwóch świadków: Aleksandra Potockiego oraz Karola Sienkiewicza, a egzekutorami ostatniej woli mieli zostać: A.J. Czartoryski, K. Kniaziewicz oraz bratanek historyka i poety - Karol Ursyn Niemcewicz ${ }^{15}$. W legacie nie tylko ujął rodzinę i przyjaciół, lecz także przekazał pieniądze, cenne przedmioty oraz pamiątki na rzecz polskiego wychodźstwa. Towarzystwu Literackiemu i Towarzystwu Pomocy Naukowej oraz Wydziałowi Statystycznemu zapisał 500 fr., natomiast Wydział Historyczny otrzymał o sto franków więcej. Ponadto J.U. Niemcewicz przeznaczył 800 fr. Towarzystwu Dobroczynności Dam Polskich w Paryżu na leki, odzież oraz żywność dla ubogich emigrantów. W swoim zapisie uwzględnił również potrzeby edukacyjne Polaków przebywających we Francji: 600 fr. pozostawił na „wydrukowanie elementarza polskiego dla dzieci polskich z dodatkiem powinności obywatelskich i rozdanie ich", a także 2000 franków - na stypendia wspierające osoby „biorące się do mechaniki i pożytecznych rzemiosł”'16.

Kasztelan testamentem objął cenne pamiątki po sobie, w tym własne rękopisy. Jego życzeniem było złożenie ich w bibliotece Wydziału Historycznego, z którym - jak już wspomniano - czuł się blisko związany. Mapy i kopersztychy zapisał K. Ursynowi ${ }^{17}$.

J.U. Niemcewicz zmarł 21 maja 1841 r. Jego śmierć pogrążyła w żałobie całą emigrację. Pamięć wybitnego Polaka uczczono nabożeństwem pogrzebowym, które odbyło się 24 maja w kościele Notre-Dame-de-l'Assomption przy ulicy Saint Honoré (parafia Wniebowzięcia Najświętszej Maryi Panny do dzisiaj pełni rolę głównej świątyni polskiej emigracji w Paryżu). Natomiast zwłoki pochowane zostały na cmentarzu Montmorency, na wzgórzu, w grobie zakupionym przez generała K. Kniaziewicza (przyjaciela pisarza), gdzie mieli spocząć razem. W ostatnim pożegnaniu uczestniczyły

14 Sam o sobie pisał w pierwszych słowach testamentu: „Gdy zgrzybiały wiek mój i osłabione do szczętu siły co dzień żywiej upominają mnie o zbliżającej się ostatniej chwili mojej; przeto oddając Bogu ducha, a ciało ziemi, czynię ten ostatni własnoręczny testament mój, wszystkie, jakiem mógł czynić dawniej, niszcząc niniejszem" - cyt. za: A.J. Czartoryski, Żywot J.U. Niemcewicza, Paryż 1860, Aneks XVIII, s. 292.

15 Zob. tamże, s. 294.

16 Tamże, s. 292.

17 Zob. tamże, s. 294. 
dziesiątki emigrantów polskich, a do grobu włożono garść ziemi ojczystej wziętej z kopca Kościuszki w Krakowie ${ }^{18}$.

Rok później, po śmierci K. Kniaziewicza, ogłoszona została publiczna składka na wspólny pomnik dla obu zmarłych. Udało się uzbierać 18000 franków. Projekt wykonał Władysław Oleszczyński i obelisk umieszczono w kościele w Montmorency ${ }^{19}$.

Zgodnie z wolą J.U. Niemcewicza większość książek, papierów i zapisków przekazanych zostało Wydziałowi Historycznemu i Bibliotece Polskiej w Paryżu. Od 1841 r. spuścizna sukcesywnie trafiała do książnicy. Z zachowanej notatki służbowej zatrudnionego w Bibliotece Kazimierza Markiewicza dowiadujemy się, że już w czerwcu spłynęły pierwsze rękopisy z lat 1836-1840 i pracownicy uważnie przeglądali ich zawartość, opisywali i pieczętowali paczki ${ }^{20}$.

W pierwszej kolejności przekazano Bibliotece manuskrypty z rzetelnie sporządzonym przez K.U. Niemcewicza 16 czerwca 1841 r. opisem darów. Wśród nich znalazły się pamiętniki, korespondencja, wypisy, druki urzędowe, ale też oryginały utworów poetyckich i prozatorskich. Opisy były konstruowane dość szczegółowo, na przykład: „1 tom oprawny z poezyami, prozą, wypisami w różnych językach - niefoliowany”, ,Seksterna własnoręcznie z roku 1841. od $1^{\circ}$ stycznia zawierający dziennik pag 1 do 96”, ,Sekstern nieszyty z 14. stronic zawierający tłumaczenie na angielski z Mickiewicza ułamki”, „Manuskrypt zaczynający się od słów «L'Europe à la fin du derrnier siècle» stronic 5”, „List do Króla angielskiego w kopercie zapieczętowany”"21.

Wyjątkowo cennym dla Biblioteki obiektem były z pewnością obszerne dzienniki. J.U. Niemcewicz opisywał $w$ nich swoje obserwacje na temat życia codziennego i wydarzeń politycznych. Rękopisy dzienników z okresu emigracyjnego dopiero w XXI w. opracowała Izabella Rusinowa ${ }^{22}$ i trzy tomy - z lat 1835-1836, 1837-1838 oraz 1839-1841 - ukazały się drukiem²3. Warto

18 Zob. I. Rusinowa, dz. cyt., s. 7.

19 Zob. L. Gadon, dz. cyt., s. 38.

20 W notatce K. Markiewicza czytamy: „Pudełko opieczętowane zawiera rożne szpargały. Paczka opieczętowana z napisem Paczka Klna Niemcewicza” - BPP, rps sygn. 1656, Notatka Kazimierza Markiewicza (dn. 15 czerwca 1841), s. 55.

21 BPP, rps sygn. 1656, „Spis manuskryptów ś.p. J.U. Niemcewicza oddających się Wydziałowi Historycznemu", s. 57.

22 I. Rusinowa (dz. cyt., s. 5-6) zwraca uwagę, że J.U. Niemcewicz podchodził do notowania z niezwykłą pasją, jednak w związku z tym miał trudności ze sprawowaniem kontroli nad tą aktywnością, co powoduje, że jego zapiski są grafomańskie i pełne usterek. Bynajmniej nie przekreśla to wyjątkowej wartości dzienników kasztelana jako źródeł do poznania dziejów politycznych i obyczajowych wychodźstwa polistopadowego.

23 Zob. J.U. Niemcewicz, Dzienniki 1835-1836, do dr. przygotowała i przypisami opatrzyła I. Rusinowa, Warszawa 2005; tenże, Dzienniki 1837-1838, do dr. przygotowała i przypisami opatrzyła I. Rusinowa, Pułtusk 2006; tenże, Dzienniki 1839-1841, do dr. przygotowała i przypisami opatrzyła I. Rusinowa, Pułtusk 2008. 
jednak pamiętać, że przekazane Bibliotece manuskrypty to tylko skromny wycinek obfitej spuścizny J.U. Niemcewicza, przede wszystkiem ta, która przebywała wraz z jej autorem na wygnaniu. Pozostałe jego rękopisy z różnych okresów działalności są rozproszone po wielu archiwach i bibliotekach polskich oraz zagranicznych. Znajdują się m.in. w Bibliotece Kongresu w Waszyngtonie, w zbiorach rodziny Kean w Elizabeth, w Uniwersytecie Princeton, w Bibliotece Uniwersytetu Cornella w Ithaca w papierach markiza Marie Josepha de La Fayette'a, a także w Bibliotece Narodowej i Archiwum Głównym Akt Dawnych w Warszawie czy w Archiwum Uniwersytetu Jagiellońskiego i Bibliotece Czartoryskich w Krakowie ${ }^{24}$.

Po przekazaniu rękopisów, w lipcu do Biblioteki trafiła pierwsza partia druków, która zawierała 41 tytułów w 98 tomach ${ }^{25}$. Pod protokołem przekazanych darów podpisał się major Józef Urbanowicz ${ }^{26}$. Publikacje znajdujące się na liście nie były podzielone na żadne działy. Wśród tomów znajdowały się zarówno dzieła polskie, jak i w języku obcym (angielskim oraz francuskim) oraz pozycje autorstwa samego J.U. Niemcewicza.

Biblioteka Polska otrzymała w darze dzieła drukowane autorstwa samego darczyńcy - wśród nich po dziewięć egzemplarzy Dziejów panowania Zygmunta III... ${ }^{27}$ oraz wydania edytorskiego Zbiór pamiętników historycznych o dawnej Polszcze. Z rękopismów tudzież dzieł w różnych językach o Polszcze wydanych, wraz z listami oryginalnymi królów i znakomitych ludzi w kraju na$s z y m^{28}$, a także ponownie Biographie du prince Adam Georges Czartoryski czy dwa wydania Niemcewicz au général Kniaziewicz, épître traduite du polonais $\mathrm{z}$ Paryża ${ }^{29} \mathrm{i}$ Tuluzy ${ }^{30}$. Bibliotece przypadł również w udziale jeden egzemplarz Levi and Sarah or The Jewish Lovers. A Polish Tale (London 1830) ${ }^{31}$.

24 Dokumenty te trafiły do wspomnianych ośrodków różnymi drogami. Na marginesie warto dodać, że J.U. Niemcewicz niekiedy sprzedawał też swoje rękopisy, np. w prowadzonych przez niego dziennikach możemy przeczytać: „Odebrałem należące mi się trochę pieniędzy za sprzedanie państwu Raczyńskim rękopisma moje dawne” - J.U. Niemcewicz, Dzienniki 1835-1836..., s. 350. Później E. Raczyński je wydawał drukiem.

25 BPP, rps sygn. 1656, Spis książek przez śp. J.U. Niemcewicza, s. 53-54.

26 Józef Urbanowicz - major powstania listopadowego na Litwie, emisariusz Czartoryskich. Członek Grona Londyńskiego - koła pomocniczego Wydziału Historycznego Towarzystwa Literackiego Polskiego. Prywatnie kolega J.U. Niemcewicza.

27 Zob. J.U. Niemcewicz, Dzieje panowania Zygmunta III, wydanie K.J. Turowskiego, Warszawa: Wytłoczono Drukiem Zawadzkiego i Węckiego Uprzywilejowanych Drukarzy i Księgarzy Dworu Króla JMci Polskiego, 1819.

28 Zob. tenże, Zbiór pamiętników historycznych o dawnej Polszcze. Z rękopismów tudzież dzieł w różnych językach o Polszcze wydanych, wraz z listami oryginalnymi królów i znakomitych ludzi w kraju naszym, Warszawa: N. Glücksberg, 1822.

29 Niemcewicz au général Kniaziewicz, épître traduite du polonais par J.-C. Ostrowski, Paris 1836.

30 J.U. Niemcewicz, Epître au général Charles Kniaziewicz, deuxième édition publiée par Alex. Jełowicki, en souvenir du quatrième anniv. de la journée du 29 novembre 1830, Toulouse [b.r].

31 BPP, rps sygn. 1656, Spisy książek, map, rękopisów pozostałych po śp. Julianie Ursynie Niemcewiczu [1842], s. 71. 
Wśród przekazanych polskich książek znalazły się dzieła tak wybitnych autorów jak: Zygmunt Krasiński, Edward Koźmian, Adam Mickiewicz, Stanisław Trembecki, Antoni Gorecki, Fryderyk Skarbek, Karol Hoffmann, Szymon Konarski, Stefan Witwicki. Ponadto było tam kilka dzieł pamiętnikarskich - np. wydanych z rękopisów nakładem hrabiego Edwarda Raczyńskiego (m.in. z serii „Obraz Polaków i Polski w XVIII wieku” publikowanej w Poznaniu od $1840 \mathrm{r}^{32}$ ) oraz inne, jak np. Podróże Paska i Sobieskiego ${ }^{33}$ czy Zbiór pamiętników o powstaniu Litwy ${ }^{34}$. Na liście znalazły się również pisma: „Kronika Emigracji Polskiej” - polityczny organ obozu A.J. Czartoryskiego, ukazujący się w Paryżu w latach 1834-1839, „Trzeci Maj” kontynuacja „Kronik”, wydawana w latach 1839-1848, „Skarbiec Historii Polskiej” - powołany w miejsce „Kronik” razem z „Trzecim Majem” i wydawany od 1839 r. przez K. Sienkiewicza czy „Kalendarz Pielgrzymstwa Polskiego", publikowany przez Eustachego Januszkiewicza w Paryżu w latach 1838-1840 pod redakcją Aleksandra Jełowieckiego ${ }^{35}$.

W grupie książek w języku obcym o Polsce lub autorstwa Polaków znalazły się m.in.: The Russo-Greek church ${ }^{36}$, Memoire sur l'état de Cracovie Ludwika Królikowskiego ${ }^{37}$, Konrad Wallenrod A. Mickiewicza (zapewne chodzi o thumaczenie na język francuski), pięć zeszytów La Pologne illustrée Leonarda Chodźki ${ }^{38}$, Le médailler de Pologne ${ }^{39}$ - drugi tom dwutomo-

32 W spisie widnieje jedynie nazwa serii, brakuje natomiasy informacji na temat poszczególnych tytułów, ilości czy dat.

33 Pod tym zapisem kryją się zapewne dwie książki: Dwie podróże Jakóba Sobieskiego, ojca króla Jana III odbyte po krajach europejskich w latach 1607-13 i 1638 (Poznań 1833) oraz Pamiętniki Jana Chryzostoma Paska z czasów panowania Jana Kazimierza, Michała Korybuta i Jana III (Poznań 1836).

34 Chodzi o publikacje Feliksa Wrotnowskiego, który w 1833 r. w Paryżu wydał Ogólny rys powstania na Litwie, i rozpoczął tym samym publikację wspomnień o powstaniu na Litwie w $1831 \mathrm{r}$. W 1837 r. ukazało się jego dzieło Powstanie na Wołyniu, Podolu i Ukrainie w roku 1831. Szerzej na temat publikacji F. Wrotnowskiego zob. K. Seroka, Feliks Wrotnowski (1803-1871), emigracyjny działacz i strażnik polskości. Dyrektor Biblioteki Polskiej w Paryżu, [w:] Wktad Polaków w kulturę Europy i świata. Skromni ludzie - wielkie dokonania, t. 1, red. A. Kamler, Warszawa 2016, s. 59-66.

35 Zob. tamże, s. 73-74.

36 Być może chodzi o odbitkę z artykułu The Russo-Greek church z „The British and Foregin Review or European Quaterly Journal” 1839, no 17, p. [319]-381 - cyt. za: Katalog KaRo, [online] $<\mathrm{http}$ ://karo.umk.pl/K_3.02/Exec/z2w_f.pl?kl=25917-1475313864\&al=x\&priority $=\& u i d=\& d i s t=2$ $\& l o k=\&$ liczba $=5 \&$ pubyearh $=\&$ pubyearl $=\&$ lang $=$ pl\&bib $=$ NUKAT\&detail $=5 \& p p=1 \& q \mathrm{q}=\mathrm{F} \& \mathrm{si}=0 \& \mathrm{p}$ $\mathrm{m}=\mathrm{f} \& \mathrm{st} \mathrm{l}=\mathrm{tt} T \mathrm{Th} \% 20$ Russo-Greek\%20 church\&di=tThe\%20Russo-Greek\%20church $>(17.10 .2016)$.

37 Zapewne chodzi o Mémoire historique et politique sur l'état actuel de la ville libre de Cracovie à l'appui de l'adresse présentée en octobre 1839, par ses habitants, aux gouvernements de France et d'Angleterre; suivi d'une collection de pièces justificatives, Paris 1840.

38 Zob. L. Chodźko, La Pologne illustrée. Contenant l'histoire de Pologne et les variétés polonaises. $X V I I I^{\circ}$ et $X I X^{\circ}$ siècles, Paris 1839-1842.

39 Zapewne: E. Raczyński, Le médailler de Pologne ou collection de médailles ayant rapport à l'histoire de ce pays depuis les plus anciennes jusqu'à celles, qui ont été frappées sous le règne du roi Jean III (1513-1696), t. 2, Breslau 1838. 
wego wydawnictwa opracowanego przez E. Raczyńskiego oraz Du crédit et de la circulation Augusta Cieszkowskiego ${ }^{40}$. Ponadto pojawiło się kilka periodyków: „La Revue Slave”"41, „Le Polonais” ${ }^{\text {, }}$, „Pologne Historique, Littéraire, Monumentale et Pittoresque" ${ }^{4344}$.

Kolejny, najobszerniejszy zbiór stanowiły książki obce. Bibliotece przekazanych zostało blisko 60 tytułów, przy czym dominowały dwa języki: francuski oraz angielski, niemniej pojawiło się również kilka dzieł po łacinie i niemiecku. Publikacje te były bardziej zróżnicowane niż omówione już polskie tytuły - znajdowały się tam na przykład pozycje encyklopedyczno-słownikowe (m.in. Dictionnaire de Briecolani ${ }^{45}$; Pocket dictionnary by Tocquot ${ }^{46}$ ), z zakresu literatury pięknej (np. poematy angielskiego twórcy Samuela Rogersa), literatura klasyczna w oryginale (m.in. Wergiliusza Opera, Horacego Carmina czy woluminy figurujące pod dość ogólnym zapisem: „Biblioteka Klasyków łacińskich"47). Wśród przekazanych publikacji nie zabrakło tych poświęconych literaturze, sztuce, ale też oczywiście sprawom polityczno-historycznym (np. Negro Population in the British Colonies ${ }^{48}$, Plebeians and patricians -2 tomy ${ }^{49}$, Contemporains illustres -2 tomy $^{50}$, Observations sur la religion ${ }^{51}$, The major of wind. Gap -3 tomy $)^{52}$ czy historii naturalnej

40 Zob. A. Cieszkowski, Du crédit et de la circulation, Paris 1839.

${ }_{41}$ Wyd. i red. przez Ksawerego Bronikowskiego w latach 1839-1840 - zob. H. Wieckowska, Bronikowski Ksawery, [w:] PSB, t. 2, Kraków 1936, s. 468-470.

42 „Le Polonais. Journal des intérêts de la Pologne”, wyd. przez Władysława Platera w latach 1833-1837.

43 „La Pologne historique, litteraire, monumentale et pittoresque, ou precis historique...”, wyd. przez Towarzystwo Literackie Polskie od 1835 r. i red. przez L. Chodźkę.

44 BPP, rps sygn. 1656, Spisy książek, map, rękopisów pozostałych po śp. Julianie Ursynie Niemcewiczu [1842], s. 75.

45 Zdaje się, że chodzi o: A. Briccolani, Nouveau dictionnaire de poche français-italien... (któreś z wydań z przed maja $1841 \mathrm{r}$.).

46 Najprawdopodobniej The royal pocket dictionary, French and English, and English and French J.F. Tocquota. Trudno ustalić, o które wydanie może chodzić - pierwsze ukazało się w 1795 r., kolejne - w 1808 r.

47 Zapewne chodzi o tomy z serii „Biblioteka Klasyków Lacińskich na Polski Język Przełożonych", wydawanej przez E. Raczyńskiego od 1837 r. Pierwszych sześć tomów ukazało się we Wrocławiu w latach 1837-1840 i te pewnie miał J.U. Niemcewicz.

48 Zapewne The Present condition of the Negro population in the British colonies: particularly in relation to the working of the apprenticeship system established under the „Act for the abolition of slavery", London 1837.

49 Plebeians and patricians, London 1836.

50 Galerie des contemporains illustres - wydawnictwo wielotomowe autorstwa Luisa de Loménie'a, którego pierwszy tom ukazał się najprawdopodobniej w $1840 \mathrm{r}$.

51 Chodzi zapewne o publikację angielskiego dyplomaty Jamesa Portera: Observations sur la religion, les loix, le gouvernement et les mœurs des Turcs. Traduit de l'anglois, par M. B***, Londres [Paris] 1769.

52 Najprawdopodobniej chodzi o: M. Banim, H.L. Martin, The mayor of Wind-gap, and Canvassing, Paris 1835 
(m.in. Dictionnaire d'histoire naturelle - 18 tomów $^{53}$ oraz Philosophie de l'histoire naturelle ${ }^{54}$ ).

J.U. Niemcewicz podarował również Bibliotece obcojęzyczne czasopisma, jak dziewięć zeszytów niekompletnego ciągu „Asiatic Journal” ${ }^{55} \mathrm{z}$ lat 1838-1839 i „The British Foreign Review”56. Ponadto wśród książek znalazło się kilka przewodników (np. po Paryżu) i atlasów geograficznych ${ }^{57}$.

Kolejna partia spuścizny wpłynęła do BPP w 1842 r. W protokole Rady Bibliotecznej z 28 kwietnia tegoż roku odnotowano, że przybyły dwa ważne zbiory: „1 188 voluminów xiążek zapisanych Bibliotece przez ś.p. J.U. Niemcewicza, $2^{\circ} 156$ voluminów ważnych dzieł rosyjskich sprowadzonych z Petersburga" ${ }^{58}$. Ten pierwszy to właśnie dar „książek przez ś.p. J.U. Niemcewicza dla Biblioteki Polskiej w Paryżu przeznaczonych i stosownie do jego woli przez P. Karola Niemcewicza do niej wniesionych" 59 .

Zarówno Karol Ursyn Niemcewicz, jak i pracownicy Biblioteki doskonale znali i rozumieli wielkość oraz znaczenie pisarza dla polskiej kultury. Dlatego też pojawił się pomysł odrębnego, całościowego potraktowania jego spuścizny. W celu jej pełnego spisania i oceny powołana została nawet specjalna komisja w dwuosobowym składzie (Teodor Morawski i K. Sienkiewicz), mająca za zadanie uporządkowanie już otrzymanych darów i sporządzenie inwentarza ${ }^{60}$. Książki spisano i podzielono na pięć działów: I. Rękopisma, II. Dzieła drukowane Niemcewicza, III. Dzieła polskie, IV. Dzieła obce (o Polsce lub napisane przez Polaków), V. Dzieła obce. Wykaz miał bardzo ogólny charakter. Autorzy spisu zawarli bardzo lakoniczny opis darowanych pozycji, zawierający jedynie tytuł (często skrócony), rzadziej - autora; brakuje daty wydania, co niekiedy utrudnia dzisiaj identyfikację dzieła. Inwentarz sporządzony został przez T. Morawskiego, dodatkowo po każdym z pięciu działów widnieje podpis jego oraz K.U. Niemcewicza.

53 Być może chodzi o: C.S. Sonnini, Nouveau dictionnaire d'histoire naturelle, appliquée aux arts, à l'agriculture, à l'économie rurale et domestique, à la médecine, Paris 1816-1817.

54 Być może: J.J. Virey, Philosophie de l'histoire naturelle; ou, Phénomènes de l'organisation des animaux et des végétaux, Paris 1835.

55 Zapewne chodzi o: „The Asiatic Journal and Monthly Miscellany”, wydawany od $1816 \mathrm{r}$. przez Kampanię Wschodnioindyjską.

56 Zapewne chodzi o „Foreign Review, and Continental Miscellany” lub inny tytuł „The Foreign Review", wydawany w Londynie w latach 1828-1840.

57 BPP, rps sygn. 1656, Spisy książek, map, rękopisów pozostałych po śp. Julianie Ursynie Niemcewiczu [1842], s. 77-79.

58 BPP, rps sygn. 1541, Protokoły Rady Bibliotecznej, Sessia 17. 28 kwietnia 1842.

59 BPP, rps sygn. 1656, Spis książek przez śp. J. U. Niemcewicza dla Biblioteki Polskiej w Paryżu przeznaczonych i stosownie do jego woli przez P. Karola Niemcewicza do niej wniesionych, s. 59-62.

${ }^{60}$ Tamże, Brulion sprawozdania komisji powołanej do zbadania spuścizny po śp. Julianie Ursynie Niemcewiczu z podpisami Teodora Morawskiego i Karola Sienkiewicza, s. 63-64. 
Po bardziej szczegółowe informacje lepiej sięgać do spisów z 1841 r., gdyż te były dokładniejsze i obszerniejsze.

Na końcu inwentarza znalazło się podsumowanie, zatytułowane „Rekapitulacja", z którego dowiadujemy się ogólnie, że do kolekcji BPP trafiło 28 dzieł J.U. Niemcewicza (tomów lub broszur), dzieł polskich - 34, dzieł obcych o Polsce lub napisanych przez Polaków - 24 oraz 108 dzieł obcych. Łącznie K.U. Niemcewicz przekazał spuściznę po Julianie Ursynie liczącą 194 tomów $^{61}$.

Niestety, w pewnym momencie scheda po J.U. Niemcewiczu przestała stanowić odrębną całość. Kolekcja uległa rozproszeniu w zbiorach Biblioteki i straciła swój pierwotny charakter. Dzisiaj o zawartości kolekcji możemy dowiedzieć się jedynie dzięki omówionym wyżej spisom i protokołom komisji zajmującej się porządkowaniem przekazanych darów.

Różnorodność biblioteki J.U. Niemcewicza świadczy o jego szerokich zainteresowaniach i ogromnej erudycji. Trzon emigracyjnej biblioteki kasztelana to głównie wydania z początku XIX w. Zaopatrywał się on przede wszystkim w dzieła emigracyjnych autorów romantycznych i tych związanych z konserwatywną stroną ówczesnej sceny politycznej, co wynikało przede wszystkim z jego własnych poglądów, ale także z potrzeby dobrej orientacji we współczesnym pisarstwie. Być może był to też sposób poety na dyskretne wspieranie finansowe często dość ubogich autorów poprzez zakup ich dzieł.

Warto zwrócić uwagę, że w przekazanych materiałach znajduje się dużo książek A. Mickiewicza i tłumaczeń jego pism. Nie jest to zaskakujące, gdyż obaj twórcy darzyli się szacunkiem, uznaniem, a nawet przyjaźnią ${ }^{62}$. Gdy w 1834 r. w kościele św. Ludwika na Île Saint-Louis odbywał się ślub A. Mickiewicza z Celiną Szymanowską, pannę młodą prowadził do ołtarza właśnie J.U. Niemcewicz. On także został ojcem chrzestnym urodzonej w 1835 r. Marii Mickiewiczówny.

Analiza zawartości zbioru z literaturą obcą dowodzi, że J.U. Niemcewicz jako poliglota o szerokich horyzontach bieżąco śledził wydania autorów zagranicznych. Szczególnie upodobał sobie traktaty historyczne, polityczne, filozoficzne i przyrodoznawcze dotyczące otaczającej go rzeczywistości. Nie pozostawał jednak obojętny na uroki poezji - równie chętnie sięgał po klasyków antycznych, jak i angielskich poetów.

61 Tamże, s. 80.

62 Serdeczny stosunek J.U. Niemcewicza do Mickiewiczów pokazują wypowiedzi kasztelana na temat tejże rodziny w jego dziennikach - np. „Pani Mickiewiczowa z domu Wołowska, z 8-miesięczną córeczką swoją Marią była u mnie na śniadaniu, biedna kobieta gryzie się położeniem męża swego, jednego z pierwszych wieszczów naszych, w ostatnim będącego niedostatku. O fortuno! Czemuż darzysz swymi naszych próżniaków i durniarzy, a talenta zostawiasz w potrzebie!" (3 czerwca 1836) - J.U. Niemcewicz, Dzienniki 1835-1836..., s. 311. 
Zapoznanie się z dziennikami J.U. Niemcewicza z czasów emigracyjnych pozwala wnioskować, że słowo pisane było dla niego niezmiernie ważne. Czasopisma i książki towarzyszyły mu do końca życia i mimo sędziwego wieku codziennie poświęcał się on lekturze. Sam pisał: „Czytanie dzienników staje się prawie nałogiem: wyglądanie ich rano: miło bowiem wiedzieć siedzącemu w domu, co się na kuli ziemskiej dzieje”63 czy „Od czytania i pisania oczy moje krwią zachodzą, pokazało się słońce, wychodzę" ${ }^{64}$. Lektura dawała kasztelanowi ukojenie ${ }^{65}$. W tych samych zapiskach odnajdziemy świadectwa silnego związku poety z Biblioteką Polską. Relacjonuje on samo otwarcie książnicy ${ }^{66}$, ale też emocjonalnie podchodzi do artykułów prasowych, które pokazują BPP w negatywnym świetle:

podał dziennik «La Nouve Elite» równie głupi, grubiański artykuł przeciw bibliotece publicznej polskiej, założenie której kosztowało tyle wydatków i zachodów w celu oświecenia rodaków, napełnienia nauką straconych chwil na próżnowaniu, gorzej jeszcze na dzikich szkodliwych przedsięwzięciach. O Boże, nie dość, że cierpię od ciemiężyciela naszego, potrzebaż żeby właśni rodacy szkalowali wszystko co dobre! ${ }^{67}$

Wracając jednak do przekazanych publikacji - może nie były one „białymi krukami”, dotyczyły raczej czasów współczesnych J.U. Niemcewiczowi, ale wiele mówią o nim samym. Jawi się on jako baczny obserwator swojej epoki i ówczesnych realiów. Dlatego jeszcze raz warto podkreślić nieocenioną wartość manuskryptów ze zbiorów J.U. Niemcewicza. Biblioteka Polska zapewniła im schronienie i przetrwanie do czasów obecnych. Jest to tym bardziej istotne, gdyż m.in. rękopisy znajdujące się w rodzinnym pałacu J.U. Niemcewicza w Skokach koło Brześcia prawdopodobnie uległy zniszczeniu podczas I wojny światowej wskutek złupienia i dewastacji dawnego majątku Niemcewiczów.

Przy analizie przekazanej kolekcji warto mieć na względzie instytucję, do której trafiły zbiory. Polityka gromadzenia książek w BPP była ukierunkowana na kolekcjonowanie takich publikacji, które później mogłyby stanowić podstawę dla utworzenia biblioteki narodowej. Gromadzono zatem dzieła

63 Tamże, s. 264.

64 Tamże, s. 370.

65 J.U. Niemcewicz wyznawał: „udałem się do quartier de l'Ecole de Médecine, do księgarza Crachard, najbogatszego w książki do historii naturalnej, kupiłem Philosophical histoire naturelle, tudzież Manier sit Instinet deux Amerique par M. De Virey. W czasie, gdzie wszystkie usiłowania nasze za straconą Ojczyznę zawodzą się, gdzie mocarstwa, byle tylko w pokoju zostać, nie dbają ni o ludzkość, ni nawet o własne sprawy, gdzie wiek gniecie i wygania z towarzystwa, gdzie i od obcych nawet i swoich ustawne przykrości, gdzie człowiek coraz bardziej wobec rodzaju ludzkiego traci szacunek, już tylko z naturą i zwierzętami żyć przychodzi” (tamże, s. 302).

66 Zob. tenże, Dzienniki 1839-1841..., s. 62.

67 Tamże, s. 110. 
historyczne, literaturę polską, opracowania z zakresu prawa czy geografii ziem polskich. Ponadto w początkowym stadium BPP miała mieć bardziej użytkowy wymiar. Co więcej, książnica stała się centrum składowania cennych pamiątek kultury polskiej, ale pełniła też funkcję archiwum emigracji, bieżąco gromadziła bowiem odpowiednią dokumentację (m.in. właśnie archiwa prywatne nie tylko emigrantów, lecz także instytucji, stowarzyszeń czy różnego typu organizacji emigracyjnych). Spuścizna po nestorze polskiej emigracji doskonale wpisywała się więc w misję i funkcję oraz w ogólny charakter gromadzonych zbiorów. Nie bez znaczenia był sam wkład J.U. Niemcewicza w tworzenie Biblioteki - kolekcja autora Śpiewów historycznych stanowi piękną pamiątkę po jego emigracyjnej działalności.

\section{Streszczenie}

Julian Ursyn Niemcewicz swoim testamentem sporządzonym w $1838 \mathrm{r}$. objął cenne po sobie pamiątki, w tym książki i rękopisy. Kasztelan życzył, by złożyć je w Bibliotece Polskiej w Paryżu, z którą był blisko związany. W artykule dokonano analizy przekazanych dokumentów (m.in. pod względem tematyki, języków czy ilości). Ponadto omówiony został proces przekazywania schedy, a także wynikające $\mathrm{z}$ tego problemy z uporządkowaniem spuścizny.

Słowa kluczowe: Julian Ursyn Niemcewicz - Biblioteka Polska w Paryżu testament - księgozbiór - dary książkowe - Wielka Emigracja.

\section{Summary}

\section{From the Last Will of Julian Ursyn Niemcewicz. Book donations to the Polish Library in Paris}

Julian Ursyn Niemcewicz included in his last will dated 1838 a valuable bequest that involved books and manuscripts. The castellan wished to have them donated to the Polish Library in Paris to which he was closely related. The article provides an analysis of the contributed documents (i.a., regarding their subject, language, and quantity). Moreover, the inheritance distribution process and the resulting issues concerning organisation of the legacy are discussed.

Key words: Julian Ursyn Niemcewicz - the Polish Library in Paris - last will and testament - book collection - book donations - the Great Emigration. 